Lapuzina O. M., Candidate of Pedagogy, Professor, Head of the Department of Natural Sciences National Technical University "Kharkiv Polytechnic Institute"

\title{
LANGUAGE OF MATHEMATICS IN L2 TEACHING
}

Summary. This article is devoted to the problem of studying language of Mathematics which aims to teach a second language (in particular, scientific style) to international students learning Mathematics in Russian.

Thematic justification of the study is determined by constantly increasing needs of students in mastering the skills of scientific style of speech which are a key priority for achieving a number of important educational goals (reading scientific and technical literature, writing scientific articles, participating in international conferences, etc.).

There are two lines of research concerning languages in their relation to Mathematics teaching. One group of researchers consider a language to be a tool for interpretation of mathematical problems, while others do not speak about language as such, but rather about discourse taking place in Mathematics classroom. In case when L2 is a language of instruction, it is Content and Language Integrated Learning (CLIL) that provides (in addition to unconditional knowledge of the subject) not only linguistic but also communicative competence.

The article gives a general characteristic of mathematical language (abstraction, consistency, accuracy, objectivity, saturation with factual information), its phonetic, lexical, morphological, syntactic peculiarities (the way of Russian pronunciation of Latin and Greek letters and mathematical expressions, reading of cardinal and ordinals numbers, mathematical symbols, fractional numbers, etc.; use of terms; use of singular instead of plural, tendency to grammaticalization of verbs, use of passive voice; frequent use of word combinations "adjective + noun" and "noun + noun in Genitive Case"; presence of different types of complex sentences, in particular with the use of subordinating conjunctions); many examples are given.

Teaching mathematical language as part of scientific style of speech involves a clear coordination of educational activities of teacher of Mathematics and L2 teacher: the former introduces supportive notes in their discipline for adequate perception of lecture material by students, and the second develops the necessary lexical and grammatical supplement to these notes. The article gives an example of lexical and grammatical supplement on the topic "Arithmetic Operations. Mathematical Signs" used in pre-lecture preparation of international students.

This approach improves listening comprehension and communication skills of students, ensures making fewer grammar mistakes, encourages scientific research, and helps in professional communication in general.

Key words: language of Mathematics, L2 teaching, Russian as a foreign language, scientific style of speech, lexical and grammatical supplement, international students.
Introduction. Language of Mathematics belongs to a functional variety of a literary language which serves various branches of science and is customary called a scientific style of speech [1], language of science [2-3], science language [4], or academic language [5-6]. When learning the scientific style, students develop a necessary level of their professional and communicative competence (listening comprehension, communication skills) which makes it possible to read textbooks in technical and natural sciences, participate in practical training in the specialty and speak on the professional topics.

According to the interview conducted among international students of pre-university level who was learning a second language (Russian) at National Technical University "Kharkiv Polytechnic Institute" in 2019-2020 academic year, almost 90\% of the respondents studied Russian for educational purposes. Subsequently, 80\% of the respondents were going to use it for reading scientific and technical literature, $50 \%$ - for business correspondence, and $40 \%$ to participate in international conferences. Thus, the Russian language is considered to be both an object of study and a tool for achieving the above objectives. And although the language of Mathematics (as the scientific style of speech in general) is most formalized and uses a large number of characters, symbols, formulae which are standard or similar for the majority of the world's languages and generally understandable even for students who do not have enough language skills, it is lack of necessary lexical and grammatical supplement that prevents those who study Mathematics (and other natural sciences) from communicating in a sublanguage of specialty.

Taking into account the fact that most of international students who have never learnt Russian begin to study Mathematics after the fourth week of classes when their language skills are not properly formed, to develop the necessary lexical and grammatical supplement for mathematical studies (as well as for other natural sciences learning) is of particular importance.

Review of literature. As it is pointed out in Sfard's review dedicated to developments in research on language and Mathematics, there are two lines of research concerning languages in their relation to Mathematics learning and teaching. One group of researchers consider a language to be a tool for interpretation of mathematical problems, while "the proponents of the other approach do not speak about language as such, but rather about discourse, a rulegoverned activity in which language is applied in particular ways by a particular community and cannot be treated apart from the activity itself" [7, p. 332]. 
It should be said, most of the works actually comprise a kind of combination of the above approaches. Novotna and Moraova use as a basis Content and Language Integrated Learning (CLIL) in accordance with which teachers should "bear in mind that not only linguistic but communicative competence (i.e., knowledge of both the language and the culture) are necessary" [8, p. 109]. According to Rizzo and Perez, "learning specific contents through the medium of English requires extra language support to access new knowledge" [9, p. 386]. Perez-Vidal and Roquet point to "new evidence regarding the linguistic progress achieved over one academic year by CLIL $<\ldots>$ in contrast with a formal instruction (FI) programme" with "reading and grammar seem to benefit the most" [10, p. 80]; after CLIL implementation "the experimental group outperformed the control group in terms of both reading skills and content knowledge" [11, p. 2169]. Arno-Macià and ManchoBares propose "integration of language in content courses and through the integration of content in ESP courses to make them more relevant to disciplines' communicative needs" [12, p. 63]. Lo and Jeong emphasise "contextualised language use $<\ldots>$ to incorporate language scaffolding in content subject lessons [13, p. 36]. Mathematical language itself like any specific language referred to those being studied for the specific purposes, possesses "three main discourse functions: description, prescription and persuasion" [14, p. 243]. It is closely connected with discourse thinking whose development is much of importance in forming discourse competence based on the understanding of the different kinds of texts for reading and listening comprehension and implies the choice of language means depending on the type of utterance in a certain communicative situation. The interaction of a teacher and students which takes place in the mathematics classroom is considered to be a basis for building "situated language of a discipline" expressing "the situated nature of mathematics" [15, p. 301].

Other important things influencing students' discursive skills should be mentioned when speaking about discursive practice. Hansson claims that "offering a learning environment that supports students' mathematics learning" can be enacted through teacher's "instruction and guidance of students in order to facilitate learning for all" - thus, students' performance is considerably higher compared with that "when much of the responsibility for students' learning is passed over to the students themselves" [16, p. 104, 119]. Planas presents "language difficulties in bilingual mathematics classrooms" experiencing of which contributes to "the creation of opportunities that may be beneficial to mathematics learning" [17, p. 52]. Barwell argues "there is a need for a more explicitly reflexive model of the relationship between content, language and learning" [18, p. 205] as exemplified by EAL (English as an additional language) students in mainstream mathematics classrooms socialized into discursive practices on solving and writing mathematical word problems.

Blazekova remarks that "the integration of course content and language teaching" is supported by current research and theory and points out to a modern trend implying a shift from "an old, formula-based approach" with "very little interaction" to "a new, inquiry and problem based communicative approach" [19, pp. 1-2].

And on this stage where much of importance is given to language proficiency (specialized communication is defined as "purposeful, informative, monolingual and multilingual, oral and written communicative acts of a specialized content" [20, p. 42], the proposed research can be considered as a contribution to methodological support for those teaching L2 students who learn Mathematics in Russian.

The purpose of this study is to provide guidance on how to prepare necessary lexical and grammatical supplement for mathematical supportive notes used as part of pre-lecture activity in CLIL environment. We hypothesise that usage of language support when teaching Mathematics to L2 students will make an educational process much more effective.

Main body of the research. Being the language of "Queen of sciences" (Gauss's words about Mathematics which became famous), the mathematical language predetermines similar linguistic features of sublanguages of natural sciences as a whole including pre-thinking statements of monologic nature, strict selection of language tools, pursuit of the normalized speech, etc. Mathematical text, stylistically clear to the scientific community, do not interfere with the perception of scientific information in the most accurate way. As written and oral forms of communication, the mathematical language can be presented in different types of the texts (text-books, reference books, scholarly articles, monographs, dissertations, lectures, abstracts, reviews). During professional communication in the classroom, it is implemented in students' reports, answers, analyses, discourses, as well as the teacher's explanations, clarifications, interpretations. Common stylistic features of the mathematical language are: abstraction, consistency, accuracy, and proof of the presentation; objectivity, and saturation with factual information.

Although the scientific information is supplied mainly in a written form, and the role of phonetic factors as a whole seems to be not that important, there are still some problems of correct pronunciation that can be referred to phonetics. Glazunova in her "Russian for Mathematicians" [21] pays a special attention to the way of Russian pronunciation of Latin and Greek letters and mathematical expressions, beginning with the introductory phonetic course; also, reading of cardinal and ordinals numbers, mathematical symbols, fractional numbers, symbols of logic and set theory, subscripts, superscripts, derivatives and powers, functions, and operators is given. Phonetic peculiarities of oral form of mathematical language, such as weakened reduction of vowels, clear pronunciation of unstressed syllables (close to letter pronunciation), are aimed at supporting its stylistic specificity and providing a quality perception of the words. Conceptual phrases tend to be separated by lengthened pauses, so that the listeners (Russian language learners) could better understand their meaning. Totally uniform and slow pace of speech is also intended to create favorable conditions for students' perception as a whole.

When presenting mathematical information, it is very important to imply one and only one meaning. That is why the usage of terms (new words that have only one definite meaning which is the same for everybody) is widely spread in the language of Mathematics. Terms tend to be unique, stylistically neutral and not to give any expression. Terms are considered to be basic conceptual lexical units in the mathematical language. Quantitatively, terms usually constitute on average $15-20 \%$ of the general lexicon, and it corresponds to the requirements made for the quantity of new lexis - "not more than $20 \%$ new words" [22, p. 206], when teaching a certificate course to first year students. Since the leading form of the mathematical thinking is a notion, almost every lexical unit in mathematical texts represents a concept or abstract object. Usual monotony and uniformity of the mathematical language leads to 
an increase in the text volume stipulated by multiple repetitions of the same words.

Morphological means are intended to emphasize the emotional neutrality of the text and promote a shift of focus to the study of the subject. Abstraction of the mathematical language stipulates the choice of morphological forms, as well as the frequency of their occurrence in the text. So, because of general domination of notions, more often usage of nouns in comparison with usage of verbs can be noted.

When almost totally excluding animate nouns, the mathematical language is rich in abstract concepts, expressed by the nouns of neuter gender with suffixes -ani, -eni, -stv (vychitanie, vychislenie, dokazatel'stvo-subtraction, calculation, proof) and feminine gender with suffixes -ost', - $k$ (delimost', formulirovka - divisibility, formulation).

In mathematical texts, a use of singular instead of plural is rather common, because singular is more appropriate to denote the generalized concept or an indivisible whole in such examples as: Primery geometricheskikh figur: treugol'nik, kvadrat, okruzhnost' (Examples of geometric shapes are: triangle, square, circle).

As for verb usage, there are some peculiarities which should be mentioned. A tendency to grammaticalization - "a change that attributes 'a grammatical character to a formerly independent word' (Meillet)" [23, p. 73] - that is, a number of verbs become copulative: byt', iavliat'sia (to be), nazyvat'sia (to be called), schitat'sia (to be considered to be), opredeliat'sia (to be defined), etc. There is also a group of verbs serving as components of verbalnominal combinations, where the main semantic burden falls on the noun denoting an action, and a verb performs grammatical role and indicates action in the broadest sense of the word, according to the grammatical meaning of modality, person and number: proizvodit' raschety (to make calculations) means the same as rasschityvat' (to calculate), and the grammaticalizied verb is proizvodit' (to calculate). A frequent usage of passive voice, because in mathematical texts it is not that important who performs the action; the object experiencing the action is of far more interest: Operatsiia nakhozhdeniia proizvodnoi ot funktsii nazyvaetsia differentsirovaniem funktsii (The operation of finding the derivative of a function is called differentiation of a function). Another morphological peculiarity of verb usage is a large number of verbs involved to characterize the properties of the objects and phenomena under study: Otrezok, soediniaiushchii dve tochki sharovoi poverkhnosti $i$ prokhodiashchii cherez tsentr shara, nazyvaetsia diametrom shara (The line segment joining two points of the spherical surface and passing through the center of the ball is called the diameter of the ball). As for verb aspects, imperfective verbs are most often used in mathematical texts, because they make present tense forms with timeless generalized meaning. Perfective verbs are used much less frequently, but they are important part in the discourses implying the structures with the meaning of "introduction to joint action": rassmotrim ...; dokazhem, chto...; pokazhem na primerakh; sdelaem vyvody o tom, chto... (let's consider; let's prove that ...; let's illustrate it with some examples; let's draw conclusions on), etc. Indicative mood clearly prevails in the mathematical language. It is followed by the subjunctive due to the fact that the results of a scientific search can be often put hypothetically. Imperative mood is quite rare with the exception of task formulation: Reshite uravneniia. Naidite oblast'opredeleniia funktsii. Vypolnite deistviia (Solve the equations. Find the domain of a function. Do the operations). It should be noted that the meaning of imperative is also expressed by infinitive: Naiti kosinus ugla mezhdu vektorami. Vychislit' ploshchad' parallelogramma (Find the cosine of the angle between the vectors. Calculate the area of a parallelogram).

At the level of phrase syntax, a frequent use of nouns in combination with adjectives is explained by the nature of mathematical language striving to tell the learner a large number of substantive meanings in most compact way. This can be clearly shown using the example of the term "funktsiia" ("function") which numbers in great many word combinations adjective + noun: kvadratichnaia funktsiia, lineinaia funktsiia, logarifmicheskaia funktsiia, monotonnaia funktsiia, nepreryvnaia funktsiia, nechetnaia funktsiia, obratnaia funktsiia (quadratic function, linear function, logarithmic function, monotone function, continuous function, odd function, inverse function), etc. Typical for the mathematical texts are word combinations noun + noun in Genetive, where the function of attribute to the head of the noun phrase is implemented by the noun in Genitive Case: sistema uravnenii, priznak delimosti, perimetr mnogougol'nika (system of equations, divisibility criterion, perimeter of a polygon). As for sentence syntax, Mathematical thought is often lengthy, detailed, and cannot be expressed in simple sentences. There is a tendency towards complexity in sentence construction to transmit a complex system of mathematical concepts and to establish the relations between cause and consequence, proof and conclusions. Various types of complex sentences, in particular with the use of subordinating conjunctions chto, chtoby, kogda, tak kak, esli (that, in order to, when, because, if) and others are used. For example: Chtoby postroit' grafik kvadratichnoi funktsii, ispol'zuiutsia nekotorye iz ukazannykh kharakteristik. Esli uravnenie $a x^{2}+b x+c=0$ imeet dva kornia, udobno ispol'zovat' koordinaty vershiny paraboly $i$ koordinaty dvukh tochek peresecheniia paraboly s os'iu $x$ (To plot a graph of the quadratic function, some of the above characteristics are used. If the equation $a x^{2}+b x+c=$ 0 has two roots, it is convenient to use vertex coordinates of parabola and coordinates of two points of intersection of parabola with $x$ axis). The interdependence of separate parts of a mathematical statement is achieved by means of specific binding words or groups of words reflecting the stages of logical presentation in discourse. They are: $v$ pervuiu ochered', snachala, dalee, tak, krome togo, odnako, sledovatel'no, $v$ zakliuchenie, $v$ rezul'tate (first of all, firstly, then, so, in addition, however, consequently, in conclusion, as a result), etc. They serve, as a rule, not for connection of words in sentences, but for unification of parts of the text as a whole. Here are some typical examples of syntactical structures widely used in the language of science: chto - eto chto; chto nazyvaetsia chem; chto delitsia na chto; chto kharakterizuetsia chem (what is what; what is called what; what is that; what is divided into what; what is characterized by what), etc. All of them can be easily found in the mathematical texts.

Based on theabovetheoreticalgrounds, we show the development of lexical and grammatical supplement to supportive notes for the topic "Arithmetical Operations. Mathematical Signs".

Supportive notes: "Mатематические знаки. - Mathematical signs: “+” плюс (plus); “-“ минус (minus); "• "умножить на (multiply by); ":"разделить на (divide by). Арифметические действия. - Arithmetical Operations: сложение (addition) $-5+3=8$, где (where) 5 - это слагаемое (an item), 3 - это тоже слагаемое (an item), 8 - это сумма (результат сложения)(a sum (result of addition)); вычитание (subtraction) -9-3=6, где (where) 9-это уменьшаемое (а тіпиелd), 3 - это вычитаемое (a subtrahend), 6 - это разность (результат вычитания) (a difference (result 
of subtraction)); умножение (multiplication) - 5.3=15, где (where) 5- это множитель (сомножитель) (a multiplier (factor)), 3 - это тоже множитель (a multiplier (factor)), 15 - это произведение (результат умножения) (a product (result of multiplication)); деление (division) - 12:3=4, где (where) 12 - это делимое (a dividend), 3 - это делитель (a divisor), 4 - это частное (результат деления) (a quotient (result of division)). $a=b-$ это равенство (an equality), “=”- будет (что?) (will be (what?)) или (or) равно (чему?) (еqual to (what?)). $5+x=10$ читаем так: (wе read): "пять плюс икс будет десять" или (оr) "пять плюс икс равно десяти”.

Lexical and grammatical supplement: 1. Word building (Nouns). The names of arithmetical operations in Russian are formed from verbs with the help of suffixes -ани, -ени used to denominate operations: вычитать $\rightarrow$ вычита-ни-е, сложить $\rightarrow$ сложeнu-e (to subtract $\rightarrow$ subtraction, to add $\rightarrow$ addition). Rusian suffix -meль with the meaning of instrument can be used in the names of masculine operands: множи-тель, дели-тель (multiplier, divisor); suffix -ocmb always goes with feminine nouns to express the name of a quality: разн-осmь (difference); suffix -cms goes with neuter nouns intended to describe a position or quality: равенcms-o (equality). Task: Find nouns with above mentioned suffixes in the text of the topic and define their gender. 2. Nominalization. Some operands in Russian are expressed by adnouns of neuter gender: слагаемое (item), уменьшаемое (minuend), вычитаемое (subtrahend), делимое (dividend), частное (quotient). 3. Word combinations noun + noun in Genitive. In word combinations of such a type, the function of attribute to the head of the noun phrase is implemented by the noun in Genitive Case: peзультаm сложения (result of addition). It should be noted that neuter nouns denoting arithmetical operations and ending with -ue change for -ия in Genitive Case: вычитание - вычитания, умножение - умножения, деление - деления. 4. Lexical and grammatical structure: что (Nom.) - равно чему (Dat.): Пять плюс икс равно десяти. Quеstion: Чему равно пять плюс uкc? (What is five plus $x$ ?)

Conclusions. Proposed lexical and grammatical supplement for mathematical education materials can be considered as a means towards professionally-oriented training, based on the needs of students in the study of a second language for specific purposes stipulated by a necessity of acquiring their future profession or specialty. Pre-lecture use of mathematical supportive notes together with the lexical and grammatical supplement improves listening comprehension and communication skills of students, ensures making fewer grammar mistakes, encourages students' research activities and their participation in scientific conferences, as well as assists in professional communication as a whole.

\section{References:}

1. Азимов Э.Г., Щукин А.Н. Новый словарь методических терминов и понятий (теория и практика обучения языкам). Москва : Икар, 2009. 448 c.

2. Halliday M.A.K. The language of science. London, New York : Continuum, 2004. 243 p.

3. Miller J.S. The language of science is in daily conversation. Science Activities. 2005. Vol. 42. No. 2. P. 3-4. DOI: 10.3200/SATS.42.2.3-4.

4. Huerta M. The impact of science notebook writing on ELL and low-SES students' science language development and conceptual understanding [dissertation]. Ann Arbor : Texas A\&M University, 2013. $210 \mathrm{p}$.
5. Mercuri S.P. The challenge of developing academic language in Spanish and English through science: the case of two teachers' strategic teaching practices [dissertation]. Ann Arbor : University of California, Davis, 2007. 268 p.

6. Chang S.M. Academic language knowledge and comprehension of science text for English language learners and fluent English-speaking students [dissertation]. Ann Arbor: University of California, Los Angeles, 2013. $141 \mathrm{p}$.

7. Sfard A. Almost 20 years after: Developments in research on language and mathematics. Review of J. N. Moschkovich (Ed.) (2010) Language and mathematics education: Multiple perspectives and directions for research. Educational Studies in Mathematics. 2013. Vol. 82. No. 2. P. 331-339. DOI: 10.1007/s10649-012-9446-2.

8. Novotná J., Moraová H. Cultural and linguistic problems in the use of authentic textbooks when teaching mathematics in a foreign language. ZDM Mathematics Education. 2005. Vol. 37. No. 2. P. 109-115. DOI: 10.1007/BF02655720.

9. Rizzo C.R., Perez M.J.M. A Key Perspective on Specialized Lexis: Keywords in Telecommunication Engineering for CLIL. Procedia-Social and Behavioral Sciences. 2015. Vol. 198. P. 386-396. http://dx.doi.org/10.1016/j.sbspro.2015.07.458.

10. Perez-Vidal C., Roquet $\mathrm{H}$. The linguistic impact of a CLIL Science programme: An analysis measuring relative gains. System. 2015. Vol. 54. P. 80-90. URL : http://dx.doi.org/10.1016/j. system.2015.05.004.

11. Chostelidou D., Griva E. Measuring the Effect of Implementing CLIL in Higher Education: An Experimental Research Project. Procedia Social and Behavioral Sciences. 2014. Vol. 116. P. 2169-2174. URL : http://dx.doi.org/10.1016/j.sbspro.2014.01.538.

12. Arno-Macia E., Mancho-Bares G. The role of content and language in content and language integrated learning (CLIL) at university: Challenges and implications for ESP. English for Specific Purposes. 2015. No. 37(1). P. 63-73. URL : http://dx.doi.org/10.1016/j.esp.2014.06.007.

13. Lo Y. Y., Jeong H. Impact of Genre-based Pedagogy on Students' Academic Literacy Development in Content and Language Integrated Learning (CLIL). Linguistics and Education. 2018. Vol. 47. P. 36-46. URL : https://doi.org/10.1016/j.linged.2018.08.001.

14. Machauf $L$. The language of civil engineering: descriptive, prescriptive and persuasive. Language Sciences. 1990. Vol. 12. No. 2-3. P. 243-254. DOI: 10.1016/0388-0001(90)90014-8.

15. Brilliant-Mills H. Becoming a mathematician: building a situated definition of mathematics. Linguistics and Education. 1994. Vol. 5. No. 3-4. P. 301-334. DOI: 10.1016/0898-5898(93)90004-T.

16. Hansson $\AA$. The meaning of mathematics instruction in multilingual classrooms: analyzing the importance of responsibility for learning. Educational Studies in Mathematics. 2012. Vol. 81. No. 1. P. 103-125. DOI: 10.1007/s10649-012-9385-y.

17. Planas N. One speaker, two languages: learning opportunities in the mathematics classroom. Educational Studies in Mathematics. 2014. Vol. 87. No 1. P. 51-66. DOI: 10.1007/s10649-014-9553-3.

18. Barwell R. Integrating language and content: issues from the mathematics classroom. Linguistics and Education. 2005. Vol. 16. No 2. P. 205-218. DOI: 10.1016/j.linged.2006.01.002.

19. Blazekova R. Learning to teach mathematics: integrating issues of content, language, and culture [dissertation]. Ann Arbor: Indiana University. 2003. 210 p.

20. Schubert K. Specialized communication studies: an expanding discipline. In: Current Trends in LSP Research: Aims and Methods. Bern : Peter Lang AG, 2012. P. 19-58.

21. Glazunova O.I. Russian for Mathematicians. Moscow : MCNMO, 2004. $360 \mathrm{p}$.

22. Safaya B.N. Teaching of language: a practical approach. Chandigarh: Abhisek Publications, 2009. $312 \mathrm{p}$.

23. Campbell L., Mixco M.J. Glossary of Historical Linguistics. Edinburgh: Edinburgh University Press, 2007. 237 p. 
Романов Ю. О., Лапузіна О. М. Математичне мовлення в навчанні другої мови

Анотація. Статтю присвячено проблемі вивчення математичного мовлення, що має на меті викладання наукового стилю студентам-іноземцям, які вивчають математику російською мовою.

Тематичне обгрунтування дослідження зумовлено постійно зростаючими потребами студентів у оволодінні навичками наукового стилю, які є ключовим пріоритетом для досягнення низки важливих освітніх цілей (читання науково-технічної літератури, написання наукових статей, участь у міжнародних конференціях тощо).

Існує два погляди на проблематику, пов'язану з використанням мови і викладанням математики. Одна група дослідників вважає мову інструментом для інтерпретації математичних задач; інші мають на увазі не мову як таку, а дискурс, що відбувається під час навчання математиці. У випадку, коли мовою навчання послуговує друга мова, йдеться про предметно-мовне інтегроване навчання, що передбачає (окрім безумовного знання предмета) не лише лінгвістичну, але й комунікативну компетенцію.

У статті надано загальну характеристику математичного мовлення (абстрактність, послідовність, точність, об'єктивність, насиченість фактичною інформацією), розглянуто його фонетичні, лексичні, морфологічні, синтаксичні особливості (зокрема: спосіб російської вимови латинських та грецьких букв і математичних виразів, читання кількісних та порядкових чисел, математичних символів, дробових чисел і т.ін.; використання термінів; використання форм однини замість форм множини, тенденція до граматизації дієслів, вживання пасивного стану; часте використання словосполучень «прикметник + іменник» та «іменник + іменник у род. відм.», наявність різних типів складних речень, зокрема із використанням підрядних сполучників); наведено багато прикладів.

Навчання математичному мовленню як складнику наукового стилю передбачає чітку координацію навчальної діяльності викладача математики і викладача другої мови: перший запроваджує опорні конспекти зі своєї дисципліни для адекватного сприйняття лекційного матеріалу студентами, а другий розробляє необхідне лексико-граматичне доповнення до них. У статті наведено приклад лексико-граматичного супроводу до теми «Арифметичні операції. Математичні знаки», що використовується у передлекційній підготовці студентів-іноземців. Даний підхід покращує сприйняття математичного мовлення та комунікативні навички у студентів, забезпечує меншу кількість граматичних помилок, заохочує до наукової діяльності та допомагає у професійному спілкуванні у цілому.

Ключові слова: математичне мовлення, викладання другої мови, російська мова як іноземна, науковий стиль мовлення, лексико-граматичне доповнення, іноземні студенти. 